\title{
The Improvement of Engineering Fluids Mechanics Teaching Based on the Mode of Active Study
}

\author{
Zhiqiang Wang \\ School of Mechanical Eng ineering \\ Hangzhou Dian zi University \\ Hangzhou, China
}

\author{
Xiaolong $\mathrm{Yu}$ \\ School of Mechanical Engineering \\ Hangzhou Dian zi University \\ Hangzhou, China
}

\author{
Jing $\mathrm{Ni}$ \\ School of Mechanical Eng ineering \\ Hangzhou Dian zi University \\ Hangzhou, China
}

\begin{abstract}
Regarding the problems of Engineering fluids mechanics's strong theory, namely vapidity, bad learning states of students, unobvious effect, we take the interest of students as guide, the project as support, and reform the mode of traditional teaching. New teaching mode will integrate students' study interest, ability of exploring and solving problems, ability of the hands-on practice and the development of team cooperation to the course, so that students could study actively and do knowledge constructions by themselves. Moreover, this paper compares the teaching mode after reform with traditional teaching mode before reform. The research shows that new teaching mode achieves remarkable results on the teaching of this course.
\end{abstract}

Keywords-autonomic learning; teaching idea; teaching reform; improvement effect

\section{INTRODUCTION}

To improve students' interests of study and to strengthen the teaching effect on class, many educationists make a series of reform and exploration for the mode of class teaching. Qin ${ }^{[1]}$ did some research for tuming teaching mode and figure out its value for changing our country's existing conception of class teaching. Aiming at existing problems on the class of universities, Zhang ${ }^{[2]}$ combined the teaching-only class with the discussion class. Then he came up with the teaching mode of "half to half class". $\mathrm{Li}^{[3]}$ made a study of how to promote teaching reform in depth and find out the basic idea of promoting the reform. To change the current situation of engineering fluids mechanics teaching, which has short teaching period, great teaching difficulty and poor learning effect, this paper takes a series of class teaching reform. It advocates to take students as main body, let students study actively and construct the knowledge by themselves. Comparing teaching effects of the teaching mode before and after reform, we can find out that new teaching mode improves learning states and effects of students obviously.

The research subjects of higher educat ion of Hangzhou Dianzi University (ZD201505)

\section{CURRENT TEACHING SITUATION OF ENGINEERING FLUIDS MECHANICS}

Engineering fluids mechanics is a course of strong theory and dull content. So it's difficult for students to learn and teachers to teach. Students' understanding of the course is not very good, main ly in the following aspects.

\section{A. Abilities of Students Are Not at the Same Level}

Engineering fluids mechanics is a main major course of mechanical engineering and marine engineering. The study of this course bases on advanced mathematics, theoretical mechanics, materials mechanics. If students don't have a good command of these courses, they will find it hard to learn this course and won't have ideal learning results. So they won't behave actively and listen carefully on class. They will bow to play mobile phones and even play truant. The appearance of these situations is worth our attention.

\section{B. Tteaching Mode Is Single and Teaching Plan Is Old- Fashioned}

Engineering fluids mechanics is of strong theory with lots of formula deductions in class. It is not only difficult for students to learn, but also hard for teachers to teach. Moreover, most presents students were born after 1995. They have strong personalities and they are interested in new things. If we still adopt traditional "spoon-feed" teaching mode ${ }^{4]}$, students" learning activities will decrease. Besides, current teaching still uses old teaching material and plan with a little change. It can't catch up with the development of current education.

\section{Teaching Hours Are Cut Down}

With the development of education for students' comprehensive development, students need to learn more knowledge. To let students finish all courses in limited time, many universities cut down some major courses' teaching hours like egineering fluids mechanics. Because of such 
change, teaching becomes more difficult and students' learning effects aren't ideal.

\section{REFORM OF TEACHING MODE}

To solve the problems of enineering fluids mechanics's short teaching hours, large theory knowledge and poor teaching effect, the author integrate the features of current traditional education, task-driving teaching ${ }^{[5-7]}$ and case teaching ${ }^{[8]}$. Then the author reforms he teaching pattern of the class he teaches and integrate students' study interests, abilities of exploring and solving problems and team cooperation spirit into the course to let students take design and practice as guide. Also, it can let them study actively and construct the knowledge by themselves. More specifically, all the knowledge that students should learn in the teaching plan launches around the core called project. The knowledge can fit the project well and form a complete organism.

\section{A. Reform of Teaching Content}

To raise students' learning interests, enhance students' understanding of professional knowledge, carry out case teaching and project design combined teaching system and adapt to students' innovation and development in teaching content, the author have a plan as follows. Firstly, we can card course system, sort out knowledge point, draw up teaching reform scheme, revise syllabus and teaching plan. Secondly, according to teaching plan, we can reform and carry out class teaching methods. Thirdly, we can reform the experiment in teaching content and combine the experiment with project to teach the experiment. Then, we can open the discussion class to let students engaged in the course. Finally, we can combine study in class with study out class to do full track ass essments for students.

\section{B. Reform of Teaching Methods}

To improve students' abilities of practice and teamwork, we should set up a platform that takes students as center, teachers as guide and project practice as orientation. Also, this platform can provide the opportunity of active study, communication and hands-on practice. Aiming at the situation of students' lack of hands-on ability, we can arrange rich design and comprehensive experiments to let all the students practice themselves and take part in the course. Moreover, we can take full advantage of computer, mu ltimedia, new network media, PPT and many other kinds of modern teaching methods This kind of teaching way is diversified. It can prevent theory teaching disjointing from practice and enhance the interaction of teaching and learning. So the teaching will transfer from principle to practice and comprehensive things and it is good for students' innovation and hands-on ability.

\section{Reform of Assessment Methods}

We can replace the rigid assessment method, which only combines usual performance with final exam, with comprehensive assessment of in-class discussion, in-class test, experimental project, participation, homework and examination paper, so that the proportion of exam mark will be cut down and students' abilities of mastering and using knowledge are paid more attention to. We will make students become real center in class, active learners.

\section{EFFECT S OF TEACHING REFORM}

In the fall semester of 2015, the author began to reform the teaching mode for the class he taught. These students use the new teaching mode to learn the course. After the course, he stated students' scores of in-class discussion, in-class test, experimental project, participation, homework and final mark "Fig. 1", "Fig. 2", "Fig. 3", "Fig. 4", "Fig. 5", "Fig. 6", "Fig. 7" and compared the scores of students who learn the course before reform. Since there are only scores of participation, homework, paper mark and final mark, comparison figures do some analysis in four aspects, as "Fig. 4", "Fig. 5", "Fig. 6", "Fig. 7" show.

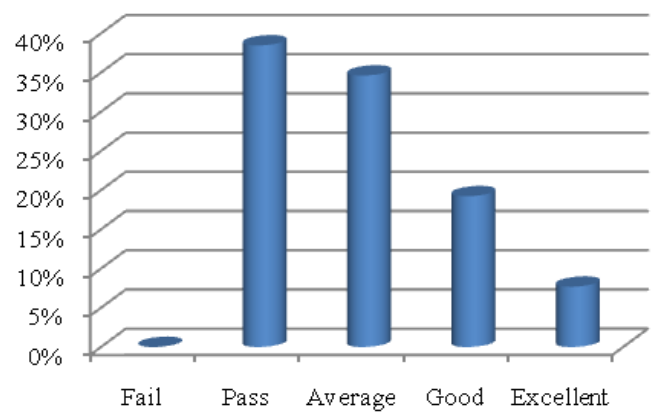

Fig. 1. In-class discussion score of pilot reform.

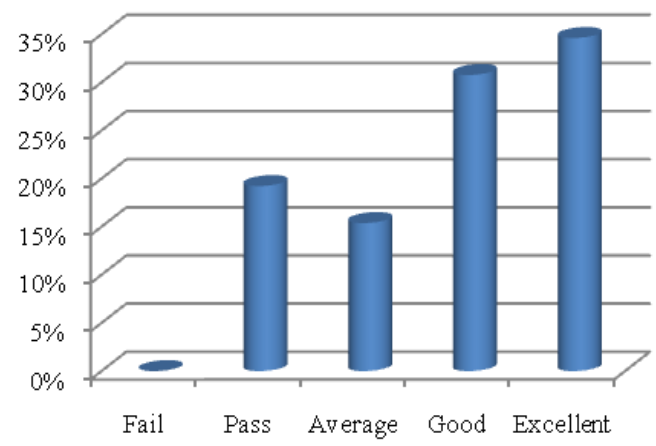

Fig. 2. In-class test score of pilot reform.

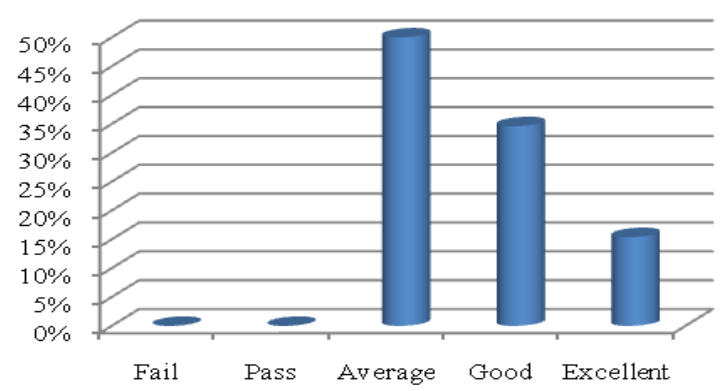

Fig. 3. Score of experimental project. 
"Fig. 1", "Fig. 2" and "Fig. 3" are students' performances of newly added discussion class, in-class test and experimental project, respectively. From students' participation of discussion in "Fig. 1", we can see that most students are at level of pass and medium, while a small part is at level of good and excellent. It indicates that students' initiative hasn't fully come out. From "Fig. 2" we can find out that the teaching method after reform is more popular. Students performed well in in-class test and the rate of good and excellent is relatively large. From "Fig. 3" we can find out that students have great interests in experimental project. Moreover, the author find that students are relatively active and careful, and are brave enough to practice, so that the score of experimental project is relatively good.

"Fig. 4", "Fig. 5", "Fig. 6", "Fig. 7" shows the comparison of students' performances of participation, homework, paper mark and final mark before and after reform. From "Fig. 4" we can find that the participation rate of students increases from 40 percent to 80 percent after reform. Also, the rate of late decreases a lot and the phenomenon of absenteeis $m$ disappears.

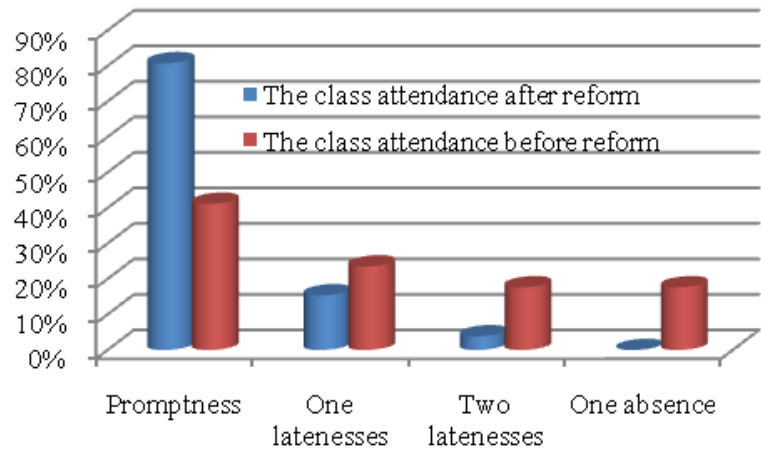

Fig. 4. Situation of participation before and after reform.

Fro $m$ the situation of homework completion in "Fig. 5", we can see that the homework of students after reform is only at the level of good or excellent. The proportion of 'excellent' is bigger and 'fail' disappears. It's a valid comparison with homework before reform.

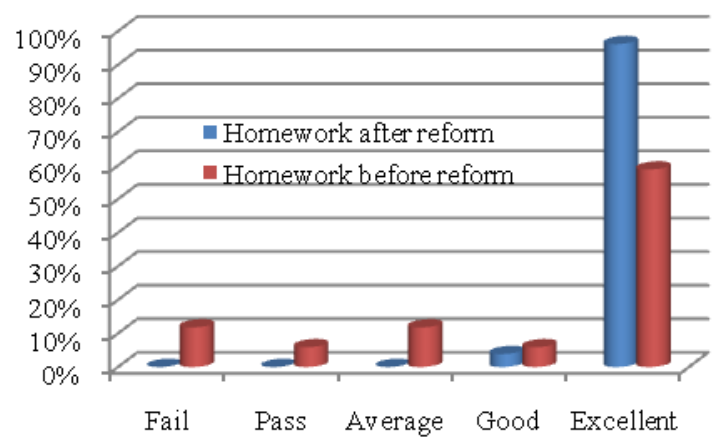

Fig. 5. Situation of homework before and after reform.

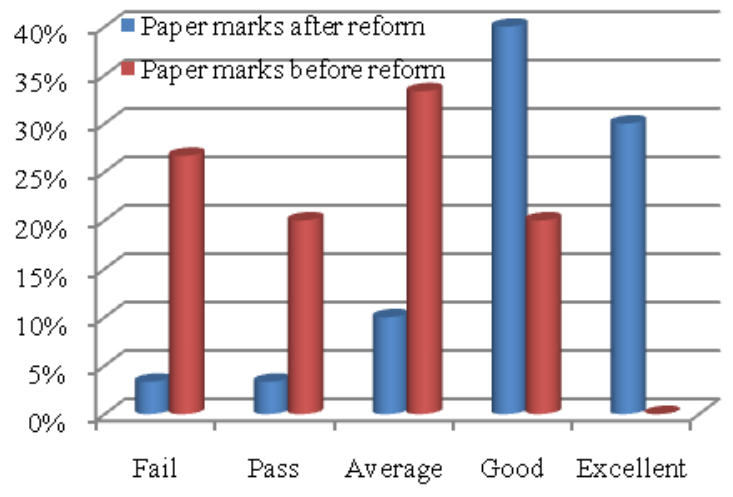

Fig. 6. Paper marks of classes before and after reform.

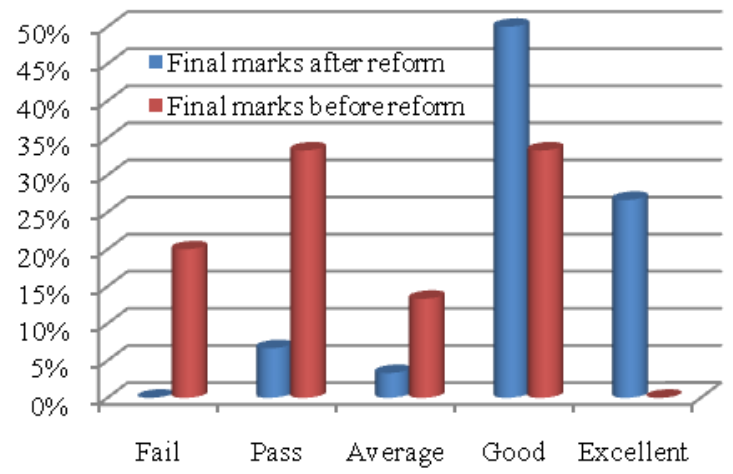

Fig. 7. Final marks of classes before and after reform.

"Fig. 6" and "Fig. 7" are students' paper marks and final marks before and after reform, respectively. From two figures, we can see that scores of students after reform most are at the level of good and excellent, while scores of students before reform don't have even one at the level of excellent. And there are many students before reform not passing the course. Although paper marks of a few students still are 'fail', all the students pass the course in final mark. So it can be seen that students' scores of class after teaching mode reform are obviously higher than scores of students receiving traditional mode. It indicates that teaching mode after reform is effective.

\section{CONCLUSION}

To develop students' ability of self-study, guide and inspire their desire for study and use their initiative, the author improves the teaching method. These improvements reflect in teaching content, teaching method, as sessment system and so on. Teaching mode after improvement is not only effective in students' ability of experimental project and students' participation, but also in students' homework completed rate and final marks. Moreover, this mode can drive students to know the application of engineering fluids mechanics and to enhance their comprehension of theory knowledge. It can improve students' abilities of communication and team working, as well as strengthen the interaction of teaching and learning. Because of it, teaching can transfer from principle to 
practice and comprehensive things and can be benefit for developing students' abilities of innovation and practice.

\section{REFERENCES}

[1] Q. Weiwei, "Turning study: new mode of class teaching reform," Eeducation Research, pp. 84-90, August 2013.

[2] Z. Xuexin, "PAD class: a new attempt in university teaching reform," Fudan Education Forum, vol. 12, pp. 5-10, May 2014.

[3] L. Songlin, "Discussion of key point of class teaching reform's development in depth," Journal of The Chinese Society of Education, pp. 28-31, February 2012.

[4] G. Liping, "Discussion of "anchored instruction" in english teaching of secondary vocational education," New Curriculum Research, pp. 65-66, May 2015.

[5] J. Xuerong, "Research of task-driven teaching mode," Journal of Lanzhou Institute of Education, vol. 29, pp. 147-148, January 2013.

[6] Z. Dan, "Discussion on the task driven teaching mode centered on the students' aut onomous learning," Education and Vocation, pp. 98-99, December 2013.

[7] W. Xiaoyi, "Application of project oriented and task driven teaching method in Warehouse Management," Education Forum, pp. 144-145, April 2015.

[8] X. Zhangtao, and G. Lingyuan, "Development of curriculum resource for subject matter knowledge: take mathematics as an example," Research in Education Development, pp. 26-30, December 2014. 